Full length article

\title{
Antimicrobial coating of spider silk to prevent bacterial attachment on silk surgical sutures
}

\author{
Albina R. Franco ${ }^{\mathrm{a}, \mathrm{b}}$, Emanuel M. Fernandes ${ }^{\mathrm{a}, \mathrm{b}}$, Márcia T. Rodrigues ${ }^{\mathrm{a}, \mathrm{b}, \mathrm{c}}$, Fernando J. Rodrigues ${ }^{\mathrm{b}, \mathrm{d}}$, \\ Manuela E. Gomes ${ }^{\mathrm{a}, \mathrm{b}, \mathrm{c}}$, Isabel B. Leonor ${ }^{\mathrm{a}, \mathrm{b}, *}$, David L. Kaplan ${ }^{\mathrm{e}}$, Rui L. Reis ${ }^{\mathrm{a}, \mathrm{b}, \mathrm{c}, *}$ \\ a 3B's Research Group, I3Bs - Research Institute on Biomaterials, Biodegradables and Biomimetics, University of Minho, Headquarters of the European Institute of Excellence on \\ Tissue Engineering and Regenerative Medicine, AvePark, Parque de Ciência e Tecnologia, Zona Industrial da Gandra, 4805-017 Barco, Guimarães, Portugal \\ b ICVS/3B's - PT Government Associate Laboratory, Braga/Guimarães, Portugal \\ ${ }^{\mathrm{c}}$ The Discoveries Centre for Regenerative and Precision Medicine, Headquarters at University of Minho, Avepark, 4805-017 Barco Guimarães, Portugal \\ ${ }^{\mathrm{d}}$ Life and Health Sciences Research Institute, School of Health Sciences, University of Minho, Braga, Portugal \\ e Department of Biomedical Engineering, Tufts University, Medford, MA 02155, USA
}

\section{A R T I C L E I N F O}

\section{Article history:}

Received 9 May 2019

Received in revised form 3 September 2019

Accepted 5 September 2019

Available online $\mathrm{xxxx}$

\section{Keywords:}

Silk Sutures, Spider silk

Antibacterial properties

Coating

Surgical site infection

\begin{abstract}
A B S T R A C T
Microbial infections from post-surgery or other medical-related procedure is a serious health problem. Nowadays, the research is focused on the development of new drug-free materials with antibacterial properties to prevent or minimize the risk of infections. Spider silk is known for its unique biomechanical properties allied with biocompatibility. Recombinant DNA technology allows to bioengineering spider silk with antimicrobial peptides (AMP). Thus, our goal was to bioengineered spider silk proteins with AMP (6mer-HNP1) as an antibacterial drug-free coating for commercial silk sutures (Perma-Hand ${ }^{\circledR}$ ) for decreasing bacterial infections. Perma-Hand ${ }^{\circledR}$ sutures were coated with 6 mer-HNP1 by dip coating. In vitro tests, using human fetal lung fibroblasts (MRC5), showed that coated sutures sustained cell viability, and also, the contact with red blood cells (RBCs) demonstrate blood compatibility. Also, the coatings inhibited significantly the adherence and formation of biofilm, where sutures coated with 6mer-HNP1 produced a $1.5 \log$ reduction of Methicillin-Resistant Staphylococcus aureus (MRSA) and a 2 log reduction of Escherichia coli (E. coli) compared to the uncoated Perma-Hand ${ }^{\circledR}$ suture. The mechanical properties of Perma-Hand ${ }^{\circledR}$ sutures were not affected by the presence of bioengineered spider silk proteins. Thus, the present work demonstrated that using spider silk drug-free coatings it is possible to improve the antibacterial properties of the commercial sutures. Furthermore, a new class of drug-free sutures for reducing post-implantation infections can be developed.
\end{abstract}

\section{Statement of Significance}

Microbial infections from post-surgery or other medical-related procedure is a serious health problem. Developing new drug-free materials with antibacterial properties is an approach to prevent or minimize the risk of infections. Spider silk is known for its unique biomechanical properties allied with biocompatibility. Recombinant DNA technology allow to bioengineering spider silk with antimicrobial peptides (AMP). Our goal is bioengineered spider silk proteins with AMP as an antibacterial coating for silk sutures. The coatings showed exceptional antibacterial properties and maintained intrinsic mechanical features. In vitro studies showed a positive effect of the coated sutures on the cell behavior. With this new drugfree bioengineered spider silk coating is possible to develop a new class of drug-free sutures for reducing post-implantation infections.

다 2019 Acta Materialia Inc. Published by Elsevier Ltd. All rights reserved.

\footnotetext{
* Corresponding authors at: 3B's Research Group, I3Bs - Research Institute on Biomaterials, Biodegradables and Biomimetics, University of Minho, Headquarters of the European Institute of Excellence on Tissue Engineering and Regenerative Medicine, AvePark, Parque de Ciência e Tecnologia, Zona Industrial da Gandra, 4805-017 Barco, Guimarães, Portugal.

E-mail addresses: belinha@i3bs.uminho.pt (I.B. Leonor), rgreis@i3bs.uminho.pt (R.L. Reis).
}

\section{Introduction}

Nosocomial infections are one of the main causes of patient mortality and morbidity after extensive surgery or other types of healthcare practices [1]. The European Centre for Disease Control 
estimates that 4.1 million people acquired a healthcare-associated infection every year in the European Union [2]. More than $20 \%$ of nosocomial infections are related to surgical site infections (SSI) $[3,4]$. These SSI represent a heavy economic burden to the healthcare systems with an estimated cost of $€ 325$ per day in Europe or $€ 22,401$ per infection in the United States $[5,6]$ due to additional post-operative surgery and longer patient hospitalization [7].

Surgical sutures are one of the most susceptible materials related to the occurrence of SSI $[8,9]$. The main function of sutures is to hold and connect tissue edges together after an injury or surgery, promoting wound healing while restricting contamination that can lead to infections. Nevertheless, sutures can harbor or introduce bacteria to enable proliferation, leading to the formation of biofilms and related infections that become problematic to treat [10-12].

Silk fibers from Bombyx mori, a natural polymer, have been used as sutures for centuries because of their high strength, especially knot-pull tensile strength, excellent physical and handling properties, as well as biocompatibility [13]. Silk sutures are used in general soft tissue closure and/or ligation, such as ocular, neural, or cardiovascular surgery [14]. Also, due to the percutaneous nature of sutures as a conduit from the environment to the tissue, they can be employed to enhance better healing for tendon/ligament repairs, for example [15]. However, one of its major drawback is related to silk sutures scarce antimicrobial properties, being necessary to treated them with antimicrobial agents in order to render them with antimicrobial properties. In fact, braided and multifilamentous silk sutures can be more susceptible to bacterial attachment, and consequently, to the formation of biofilms $[16,17]$. For preventing and overcoming the formation of bacterial biofilms, braided suture materials with antibacterial properties were envisaged. Moreover, antimicrobial coating should not negatively alter suture properties, such as tenacity, knot strength, surface friction, or biocompatibility characteristics. Silk sutures have been coated with different antibiotics, such as tetracycline [18], gentamicin [19], levofloxacin [17,20], among others, to prevent bacterial adherence and the formation of biofilms. Other antibacterial agents, like chitosan [21,22] or silver ions [23] have also shown a similar effect in preventing bacterial colonization of medical materials. Furthermore, the increasing of microbes resistant to antibiotics or antibacterial agents like triclosan, has pushed current research to look for alternative substances with antimicrobial properties to prevent SSI and at the same time to reduce the administration or use of antibiotics [24].

Antimicrobial peptides derived from the human innate immune system offers a new prospective source of antimicrobial candidates with extended clinical lifetimes [25]. However, due to the labile nature of peptides and potential toxicity concerns of most antimicrobial peptides, their period of action can be reduced, with lower protein stability or inefficient delivery of the antimicrobial peptide to the target site, hindering their clinical development [26]. Human Neutrophil Defensin-1 (HNP1) is an $\alpha$-defensin that belongs to a large a subfamily of cationic antimicrobial peptides with known activity against a broad range of microorganisms, with preference against Gram-positive bacteria [27-29]. The antimicrobial potential of other $\alpha$-defensins has also been reported. For instance, HNP4 is more active against Gram-negative bacteria than to Gram-positive bacteria [30,31]; while HNP2 and HNP3 have predominant antibacterial activity against Staphylococcus aureus or Escherichia coli [30]. In fact, HNP1 or other similar antimicrobial peptides may represent an alternative to antibiotic agents due to their low toxicity against mammalian cells, promoting the development of protective immune responses, and thus functioning as adjuvants [32]. Dabirian et al. [32] reported that the infectivity of Leishmania spp. on cells was significantly reduced in the presence of recombinant HNP-1. Also, Sharma et al. [33] reported the thera- peutic potential of HNP1 against Mycobacterium tuberculosis in in vivo studies.

Currently, new strategies have been explored for delivering antibacterial peptides, for example using functionalized gold nanoparticles to deliver antimicrobial peptides to the wound site infections [34]. In the last years, bioengineered spider silk proteins have been widely explored as novel biopolymers. Spider silk are natural protein polymer with unique chemical and physical properties, excellent biocompatibility, absent or minimal immunogenicity, and controllable biodegradability, making them suitable for different applications in the biomedical field [35-37]. Through recombinant DNA technology, we can design and functionalized spider silk chimeric proteins with antimicrobial peptides (AMP) $[38,39,34]$. Our purpose is to engineer chimeric proteins with antimicrobial properties by recombinant DNA technology and use them as a coating for commercial silk surgical sutures in order to prevent or reduce SSI. In this work the importance of designing spider silk-based protein functionalized with antimicrobial domains instead of using AMP only, relies on the fact that the recombinant protein (6mer-HNP1) retain the antimicrobial properties of HNP1 plus the $\beta$-sheet formation capability even after adding the antimicrobial domains. The maintenance of the capacity to form $\beta$-sheet is important, since these physical cross-links are responsible for the exceptional mechanical properties, stability and slow degradability of silk $[38,39]$. Furthermore, due to HNP1 peptide nature, these biomolecules are more susceptible to proteolytic digestion [40]. Therefore, their combination with spider silk proteins may represent an advantage by decreasing proteolytic digestion [41] and by allowing for more to prolong effectiveness over time.

To achieve this goal, commercial silk sutures (Perma-Hand ${ }^{\circledR}$ ) were coated either with the spider silk protein alone (6mercontrol) or with the spider silk protein with antimicrobial peptide (6mer-HNP1-treatment group). The mechanical properties as well as cytotoxic/hemolytic behavior of the novel coated sutures and antibacterial properties against Methicillin-Resistant S. aureus (MRSA, Gram-positive) and E. coli (Gram-negative) were investigated.

\section{Material and methods}

\subsection{Production of the bioengineered spider silk proteins 6mer-HNP1 and $6 \mathrm{mer}$}

The bioengineered spider silk protein 6mer consists of six repeats of the consensus sequence motifs derived from the major ampullate dragline silk I protein from Nephila clavipes (MaSp1; Accession number P19837) [39]. As for the bioengineered spider silk protein 6mer-HNP1, the DNA encoding the antimicrobial peptide HNP1 was inserted in the pET30 vector already containing the recombinant spider silk protein 6mer [39]. The production of the bioengineered proteins 6mer-HNP1 and 6mer was made in E. coli and the purification of these proteins were performed as previously described [39]. Briefly, overnight bacteria cultures were grown in $100 \mathrm{~mL}$ Luria-Bertani (LB) broth medium supplemented with $50 \mu \mathrm{g} / \mathrm{ml} \mathrm{kanamycin}$ at $37^{\circ} \mathrm{C}$ and used to inoculate $1 \mathrm{~L}$ of HyperBroth (0107; Athens Enzyme Systems Protein Expression) supplemented with $50 \mu \mathrm{g} / \mathrm{ml}$ kanamycin at $37^{\circ} \mathrm{C}$ with agitation (250 rpm) until an OD600 of 0.7-0.9 was reached. Protein expression was induced by adding isopropyl $\beta$-D-thiogalactoside (IPTG) at a final concentration of $1 \mathrm{mM}$ for $4 \mathrm{~h}$, and harvest by centrifugation at $8000 \mathrm{rpm}$ for $20 \mathrm{~min}$ at $4{ }^{\circ} \mathrm{C}$. The cell pellet was placed at $-20^{\circ} \mathrm{C}$ for $12 \mathrm{~h}$, thawed in ice for $30 \mathrm{~min}$, and then resuspended overnight in a denaturating buffer $\left(100 \mathrm{mM} \mathrm{NaH}_{2} \mathrm{PO}_{4}, 10 \mathrm{mM}\right.$ Tris $\mathrm{HCl}, 8 \mathrm{M}$ urea, $\mathrm{pH} 8.0$ ) at $4{ }^{\circ} \mathrm{C}$. Lysate supernatant was recovered by centrifugation at $8500 \mathrm{rpm}$ for $30 \mathrm{~min}$ at $4{ }^{\circ} \mathrm{C}$, removing cell debris and the 
lysate was then added to a 50\% Ni-NTA slurry in a ratio $1: 4(\mathrm{Ni}-$ NTA: lysate), and mixed gently overnight at $4{ }^{\circ} \mathrm{C}$. The supernatant/Ni-NTA resin mixture was added onto a glass Econocolumn (Biorad), and washed with denaturating buffer (see above) at $\mathrm{pHs} 8$ and 6.3 . The recombinant proteins were eluted with denaturating buffer at pH 5.8 and 4.5 and then analyzed by SDSPAGE to confirm protein purification. Proteins were dialyzed into cellulose ester snakeskin membranes with a 100-500 Da molecular weight cutoff (Spectra/Por Biotech, 131054), for one day, on $100 \mathrm{mM}$ sodium phosphate buffer ( $\mathrm{pH} 5.5$ ), to maintain a steady $\mathrm{pH}$ and avoid protein precipitation. Afterward, extensive dialysis against water was followed for three days to remove all salts. Finally, the dialyzed proteins were lyophilized. The purity of the recombinant proteins, 6 mer and 6mer-HNP1, was confirmed by SDS-PAGE using a Bis-Tris 4-12\% gels (NuPAge, Invitrogen) and staining with Coomassie blue.

\subsection{Materials}

Commercial, non-absorbable, multifilament silk sutures (black, size 3/0 USP; Perma-Hand ${ }^{\circledR}$, Ethicon, USA) was used for the preparation of the antibacterial sutures, and also used as a control. Absorbable multifilament polyglactin 910 sutures containing triclosan antibacterial agent (violet, size $3 / 0$ USP; VicrylPlus ${ }^{\circledR}$ Antibacterial, Ethicon, USA) were used as a control in the antibacterial tests.

\subsection{Preparation of sutures coated with bioengineered proteins}

Prior to coating, the Perma-Hand ${ }^{\circledR}$ sutures were soaked in $5 \mathrm{~mL}$ of a $0.1 \mathrm{~N} \mathrm{NaOH}$ solution for $2 \mathrm{~h}$, followed by washing three times with sterile deionized $\mathrm{H}_{2} \mathrm{O}$ to remove wax coatings or impurities present in the sutures. The sutures were coated with 6 mer or 6mer-HNP1 proteins using dip-coating technique, which is a well-established method for different materials and applications. Moreover, it has been demonstrated that this process is facile and effective as a surface treatment of fibrous materials, like silk sutures, including dip-coating in a solution containing a synthetic polymer or other antimicrobial compounds, which can be immobilized on the suture surface [16]. Two different protein solutions were used: (i) $2 \%$ of the 6 mer and (ii) $2 \%$ of 6 mer-HNP1. The concentration of protein solution used ( $2 \%$ ) was chosen based on a previously published study [39]. Briefly, the protein 6 mer or 6 merHNP1 (1 mg) were dissolved in $5 \mathrm{~mL}$ of ultrapure water and uncoated sutures $(20 \mathrm{~cm})$ were dipped for $120 \mathrm{~s}$, followed by a drying period of $120 \mathrm{~s}$ at room temperature. This process was repeated four times for obtaining uniform coating along the suture length. After the drying process, the coated sutures were placed into a $70 \%$ methanol solution for $2 \mathrm{~h}$, to allow the formation of $\beta$-sheet, thus rending the silk coating water insoluble.

The diameter and weight of the coated and uncoated PermaHand $^{\circledR}$ sutures were measured at five different positions along the length of the suture. The average diameter of each type of suture was calculated using an electronic thickness gauge and expressed in $\mathrm{mm}$. The weight of each type of suture was determined using a precision electronic balance (TB2150, Denver Instruments, Germany) and expressed in mg. The weight concentration of the protein coating on the sutures was also calculated as the amount of protein coating normalized per length of suture (mg/ $\mathrm{cm})$, according to Obermeier et al. [8].

\subsection{Characterization of the coated sutures}

The surface of the Perma-Hand ${ }^{\circledR}$ suture uncoated and coated with 6mer and 6mer-HNP1 proteins were examined by Highresolution field emission scanning electron microscope (SEM, Aur- iga Compact, Zeiss, Germany). Prior to any SEM observations, all sutures types were sputter-coated with palladium by ion sputtering (EM ACE600, Leica, Germany).

The tensile strength of the coated and uncoated Perma-Hand ${ }^{\circledR}$ sutures were assessed by the straight-pull and knot-pull uniaxial tests, using an Instron 5540 Universal Machine (USA) with a load cell of $1 \mathrm{kN}$. The straight-pull tensile tests were carried out at a crosshead speed of $2 \mathrm{~mm} / \mathrm{min}$ and a gauge length of $10 \mathrm{~mm}$ until rupture, and the maximum tensile strength and strain values at rupture were determined. The knot-pull tensile test was performed using a simple knot, according to the European Pharmacopoeia standard [42] (01/2005:0324 standard; minimum required for $U$. S. Pharmacopeia (USP) [43] 3-0 non-absorbable sutures are 9.41 $\mathrm{N}$ or $20.9 \mathrm{GPa}$ ). Briefly, a simple knot was formed by placing one end of a suture held in the right hand over the other end held in the left hand, passing one end over the suture and through the loop so formed and pulling the knot tight. The length of suture between the clamps was $12.5 \mathrm{~cm}$ and the knot was midway between the clamps and driven at a constant rate until rupture, as mentioned above.

The tensile modulus was estimated from the initial slope of the stress-strain curve using the linear regression method. Five specimens per condition were tested and the results are expressed as means \pm standard deviation.

\subsection{In vitro degradation of the coated sutures}

In vitro degradation of the coated and uncoated Perma-Hand ${ }^{\circledR}$ sutures was assessed in the presence and absence of protease XIV from Streptomyces griseus (Sigma). Pre-weighed coated and uncoated sutures $(10 \mathrm{~mm}$ in length) were individually immersed in $5 \mathrm{~mL}$ of phosphate-buffered saline (PBS) solution containing $1 \mathrm{U} / \mathrm{mL}$ protease XIV for $0,1,4$, and 7 days at $37^{\circ} \mathrm{C}$. The enzymatic solution was changed every 2 days. A control, in PBS only, was also performed. After each degradation period, the specimen were rinsed with distilled water, dried overnight at $37^{\circ} \mathrm{C}$ and weighed.

The percentage of weight loss of each specimen was determined according to the following equation:

$\%$ Weight loss $=(\mathrm{mi}-\mathrm{mf}) / \mathrm{mi} \times 100 \%$

where mi indicates the initial dry weight and mf the dry weight at different time points $(n=4)$. The results are expressed as means \pm standard deviation.

\subsection{Antibacterial properties}

The antibacterial properties of the Perma-Hand ${ }^{\circledR}$ suture coated either with 6 mer or 6mer-HNP1 proteins were assessed against MRSA and E. coli. Prior to the antibacterial tests, coated sutures (10 $\mathrm{mm}$ in length) were sterilized using a $70 \%$ ethanol solution for $2 \mathrm{~h}$, washed three times in sterile PBS ( $\mathrm{pH} 7.4$ ) and dried overnight in a flow chamber. Sterile commercial Perma-Hand ${ }^{\circledR}$ sutures and VicrylPlus ${ }^{\circledR}$ Antibacterial suture were used as controls. Bacterial cultures were grown in LB broth medium at $37^{\circ} \mathrm{C}$ overnight with agitation $(150 \mathrm{rpm})$. Cells were centrifuged at $9000 \mathrm{rpm}$ for $5 \mathrm{~min}$ at $4{ }^{\circ} \mathrm{C}$, and the bacterial pellet washed twice with sterile PBS ( $\mathrm{pH} 7.4)$. Bacterial cells were re-suspended in sterile PBS $(\mathrm{pH}$ 7.4 ) and adjusted to an optical density of $0.3(\lambda=610 \mathrm{~nm})$. Coated sutures and controls were immersed in $1 \mathrm{~mL}$ of LB medium inoculated with $3.1 \times 10^{6}$ or $2.1 \times 10^{6}$ of $E$. coli and MRSA, respectively, and incubated at $37^{\circ} \mathrm{C}$ for $24 \mathrm{~h}$. Afterwards each suture was washed and placed in $1 \mathrm{~mL}$ of PBS (pH 7.4) and sonicated for $20 \mathrm{~s}$ with $5 \mathrm{~s}$ impulses to remove the attached bacteria on the sutures. Then, serial dilutions were made and spread onto LB agar plates and incubated overnight at $37^{\circ} \mathrm{C}$. The adherent viable bacteria to 
the sutures were evaluated as log reduction of the colony forming units (CFU mL $\mathrm{mL}^{-1}$ ). Each experiment was performed in triplicate.

The viability, adherence and formation of bacterial biofilms on the coated sutures and controls were further analyzed by Live/ Dead staining and SEM as previously described [39]. Briefly, after $24 \mathrm{~h}$ incubation, each suture was washed twice with sterile PBS (pH 7.4) and stained with $1 \mathrm{~mL}$ solution of a Live/Dead ${ }^{\circledR}$ Bacterial Viability Kit (Molecular probes, L7007, Invitrogen) for $15 \mathrm{~min}$ at room temperature. Afterwards, sutures were washed three times with sterile PBS (pH 7.4) to remove excess dye. Live bacteria were stained green using SYTO 9 and Dead bacteria were stained red using PI and visualized using a Fluorescence Microscope (Imager Z1m, Zeiss), under $40 \times$ magnification. Four random images were acquired using a digital camera (AxioCam MRm5, Zeiss) and analysed by ImageJ (NIH, Maryland, USA). For SEM, sutures were fixed with $4 \%$ glutaraldehyde for $60 \mathrm{~min}$ in the dark at room temperature. Suture samples and control materials were dehydrated in a series of ethanol-water solutions with increasing ethanol concentration twice $(50,70,80,90$, and $100 \%, v / v)$ and left to dry overnight prior to coating with palladium by ion sputtering.

\subsection{Cytotoxicity}

The biological behavior of the coated sutures with 6 mer or 6mer-HNP1 fusion proteins was assessed using a cell line from human fetal lung fibroblasts (MRC5). Sterile commercial PermaHand $^{\circledR}$ sutures were also used as a control material. Coated suture materials were sterilized as described in Section 2.6. Prior to cell seeding, cells were cultured in Dulbecco's modified Eagle's medium (DMEM) supplemented with $10 \%(\mathrm{v} / \mathrm{v})$ fetal bovine serum (FBS), $1 \%$ penicillin-streptomycin (v/v) at $37{ }^{\circ} \mathrm{C}$ with $5 \% \mathrm{CO}_{2}$ under a humidified environment. After reaching 70\% confluence, cells were trypsinized $(0.25 \%$ trypsin/EDTA solution) from the culture flask. The sterile coated sutures and controls were cultured in 24-well plates with $100 \mu \mathrm{L}$ of a cell suspension containing approximately 40,000 cells and incubated for $4 \mathrm{~h}$ at $37{ }^{\circ} \mathrm{C}$ with $5 \% \mathrm{CO}_{2}$ in a humidified environment. After incubation, $900 \mu \mathrm{L}$ of DMEM medium was added and the cultures were incubated for 1 and 3 days under the same conditions as mentioned above. MRC5 cells cultured onto tissue culture polystyrene (TCPS) with DMEM were used as a negative control. MRC5 metabolic activity was determined by Alamar Blue assay (BUF012B, Bio-Rad), according to the manufacturer instructions. Briefly, DMEM medium was removed from each well after the specific incubation time. Cells were washed twice with sterile PBS (pH 7.4) and $1 \mathrm{~mL}$ of an Alamar Blue solution (1/10 in DMEM; $\mathrm{v} / \mathrm{v}$ ) was added directly to each well and incubated for $4 \mathrm{~h}$ at $37{ }^{\circ} \mathrm{C}$ with $5 \% \mathrm{CO}_{2}$. The metabolic activity was recorded by fluorescence at an excitation wavelength of $570 \mathrm{~nm}$ and emission at $585 \mathrm{~nm}$. Data was normalized by DNA content to account for variation in cell number. Samples without cells were used as controls.

MRC5 cell proliferation was also evaluated by dsDNA picogreen quantification (P11496, Invitrogen), according to the manufacturer's instructions. Briefly, after each incubation time, DMEM medium was removed from each well and cells were washed twice with sterile PBS ( $\mathrm{pH} 7.4$ ). Then, $1 \mathrm{~mL}$ of ultrapure water was added to each well to induce complete membrane lysis, incubated at $37{ }^{\circ} \mathrm{C}$ for $1 \mathrm{~h}$ and stored at $-80^{\circ} \mathrm{C}$ until further analysis. After thawing, samples were analyzed for DNA content and measured at an excitation wavelength of $485 / 20 \mathrm{~nm}$ and at an emission wavelength of $528 / 20 \mathrm{~nm}$. DNA content was calculated according to a standard curve. The experiments were run in triplicate.

\subsection{Evaluation of the hemolytic activity of the coated sutures}

In the case of materials used as blood contacting devices, blood compatibility should be assessed to establish safety. The red blood cell damage was assessed when exposed to the coated and uncoated Perma-Hand $^{\circledR}$ sutures as well as reference silk sutures. The coated and uncoated Perma-Hand ${ }^{\circledR}$ sutures, as well as the reference materials (medical steel, silicone and rubber), were cut into $0.5 \mathrm{~cm}^{2}$ pieces and sterilized as described in Section 2.6. The hemolytic activity of all materials was evaluated using the Haemoscan Hemolytic Assay [44] (HaemoScan bv, Groningen, Netherlands) according to the manufacturer's protocol. This method is adequate to evaluate the hemocompatibility of biomaterials and medical devices according to the international standard ISO 109934:2009. First, the commercial supplied whole blood of human origin (Haemoscan Hemolytic Assay kit component tested and confirmed negative for HbsAg, HCV, HIV I/II, HTLVI/II and Treponema) was centrifuged at $3000 \mathrm{rpm}$ for $10 \mathrm{~min}$ to isolate red blood cells (RBCs), discarding plasma and white blood cells. RBCs $(1 \mathrm{~mL})$ were diluted in $9 \mathrm{~mL}$ of Tris buffer solution (TBS; $10 \mathrm{mM}$ Tris buffer, $\mathrm{pH}=7.0,150 \mathrm{mM} \mathrm{NaCl}$ ), and diluted by a factor of 40 as a RBC stock suspension [45]. All materials were washed three times with sterile $\mathrm{dH} 2 \mathrm{O}$ distilled water, followed by rinsing with physiological saline solution $(150 \mathrm{mM}$ of $\mathrm{NaCl})$ three times before incubation with the RBCs. Then, all the materials were individually immersed in a tube containing $120 \mu \mathrm{L}$ of a working solution of $10^{7}$ of $\mathrm{RBC} / \mathrm{mL}$ (corresponding to $0.25 \%$ of the red blood cells stock solution) in TBS buffer $(150 \mu \mathrm{L})$, and incubated in a water bath at $37^{\circ} \mathrm{C}$ for $24 \mathrm{~h}$. Afterward, all materials were removed from the tube and the fluid medium was centrifuged at $1000 \mathrm{rpm}$ for $5 \mathrm{~min}$. The supernatant liquid $(30 \mu \mathrm{L})$ was removed and diluted with $100 \mu \mathrm{L}$ of TBS buffer. RBCs in TBS buffer without any materials was used as negative control and $0.1 \%$ Triton X-100 in TBS buffer as a positive control. Hemolytic activity was calculated spectrophotometrically at OD 450, 425 and $380 \mathrm{~nm}$, according to the Harboe method [46]. Hemoglobin concentration was quantified against a standard curve.

\subsection{Statistical analysis}

All the quantitative results were obtained from triplicate samples. In the case of the mechanical tests, four replicates were analyzed per each treatment. Data are reported as mean \pm standard deviation and tested for normality. For statistical analysis, a oneway ANOVA test was performed using GraphPad Prism 6.0 software. Means were compared using the Tukey post hoc test for multiple comparisons when a significant F-value was obtained $(\mathrm{P}<0.05)$. In the degradation tests, the weight loss of PermaHand ${ }^{\circledR}$ sutures coated and uncoated were compared by unpaired $t$-test with an interval of confidence of $95 \%$.

\section{Results and discussion}

\subsection{Bioengineered spider silk proteins 6mer-HNP1 and 6mer production}

The colonization and biofilm formation by bacteria pathogens on surgical suture is currently one of the most serious healthrelated problems often leading to SSI [47]. Synthetic absorbable surgical sutures coated with antibacterial compounds (i.e. VicrylPlus ${ }^{\circledR}$ Antibacterial suture) were developed [12] aiming to reduce post-operatory surgical site infections. However, so far, in the case of non-absorbable surgical sutures like Perma-Hand ${ }^{\circledR}$ silk suture, there is no commercialized silk suture materials with antibacterial properties. Moreover, the exhaustive use of antimicrobial compounds to prevent or fight microbial infections led to an increase of multi-resistant pathogens [48], making it urgent to develop new drug-free antibacterial coatings for surgical silk sutures surfaces as real alternatives to antibacterial compounds. 
In the present study, we explored the use of a bioengineered spider silk protein with antibacterial properties, 6mer-HNP1, as new an antibacterial drug-free coating for Perma-Hand ${ }^{\circledR}$ silk suture. Perma-Hand ${ }^{\circledR}$ silk sutures coated with 6 mer or uncoated were used as controls. Fig. 1 shows the successful expression and purification of the fusion proteins 6mer-HNP1 and 6mer analyzed by SDS-PAGE. The molecular weight of 6 mer and 6 mer-HNP1 were determined as $27 \mathrm{kDa}$ and $30 \mathrm{kDa}$, respectively. Protein sequencing enabled the confirmation of $\mathrm{N}$ - and $\mathrm{C}$-terminal of the proteins, especially the insertion of the HNP1 gene in the spider silk 6mer protein.

\subsection{Characterization of the coated sutures}

The bioengineered protein 6mer-HNP1 already demonstrated broad antimicrobial activity against well-known pathogens when used in solution or in films combined with silk fibroin [39]. Herein, the bioengineered spider silk proteins, 6mer-HNP1 and 6mer, were applied as coatings on the braided silk sutures using a dip-coating approach. After dip coating process, weight concentration of the coating on the sutures was calculated. In the sutures coated with 6 mer protein, the weight concentration on the coated suture with 6 mer was $11.0 \pm 0.3 \mu \mathrm{g} / \mathrm{cm}$ and in the coated suture with 6 merHNP1 of $10.8 \pm 0.5 \mu \mathrm{g} / \mathrm{cm}$. The surface morphology of the sutures uncoated and coated with 6mer or 6mer-HNP1 were observed by SEM (Fig. 2).

A typical braided structure of the multifilament silk sutures was observed in all type of sutures, coated with 6mer (Fig. 2A) or 6merHNP1 (Fig. 2B) or uncoated sutures (Fig. 2C). In the coated sutures, a non-uniform distribution of the bioengineered proteins (6mer and 6mer-HNP1) along the multifilament sutures was observed (Fig. 2A, 2B). These non-uniform coating is probably due to the formation of protein aggregation in the last dipping layer. In fact, spider silk protein self-assembly procedure in aqueous solutions can result in the formation of nanofibril structures due to the selfassembly features of the proteins. Spider silks retain its intrinsically unstructured conformation in aqueous solution but can selfassemble into nanofibrils depending on the solution conditions $[49,50]$. Nevertheless, the application of spider silk proteins as a coating did not affect the morphological structure of the silk braided sutures.

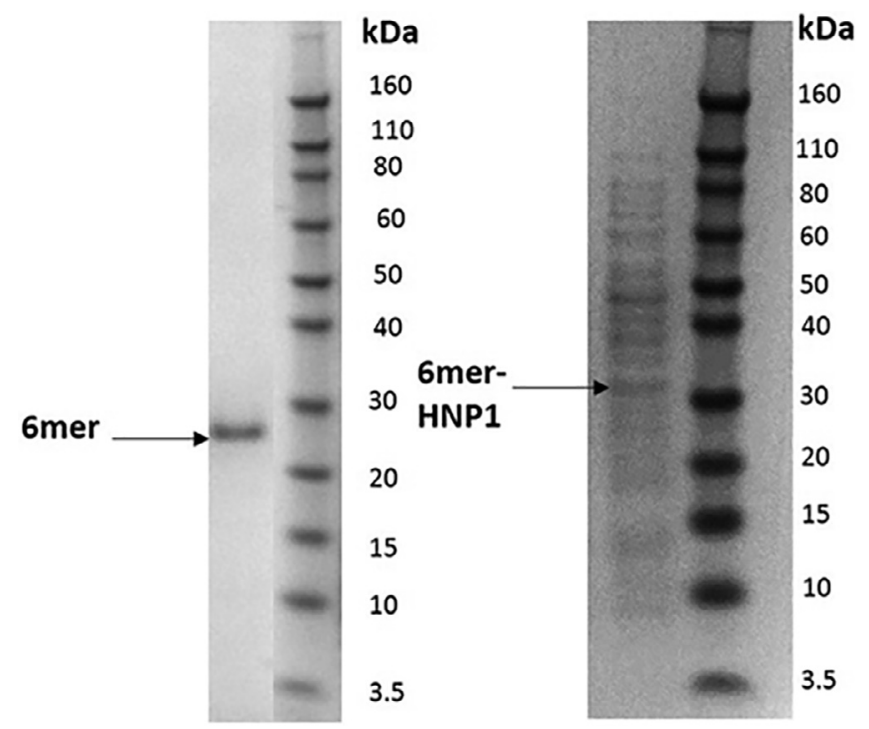

Fig. 1. SDS-PAGE gel electrophoresis demonstrating the expression of 6 mer and 6 mer-HNP1, with molecular weight around $27 \mathrm{kDa}$ and $30 \mathrm{kDa}$, respectively.

\section{Perma-Hand $®$ suture coated with $6 \mathrm{mer}$}

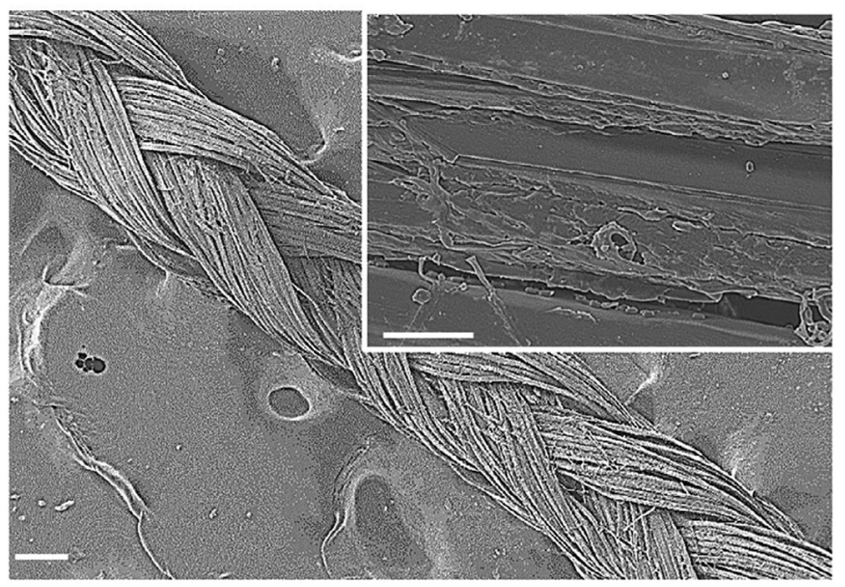

\section{Perma-Hand® suture coated with 6mer-HNP1}

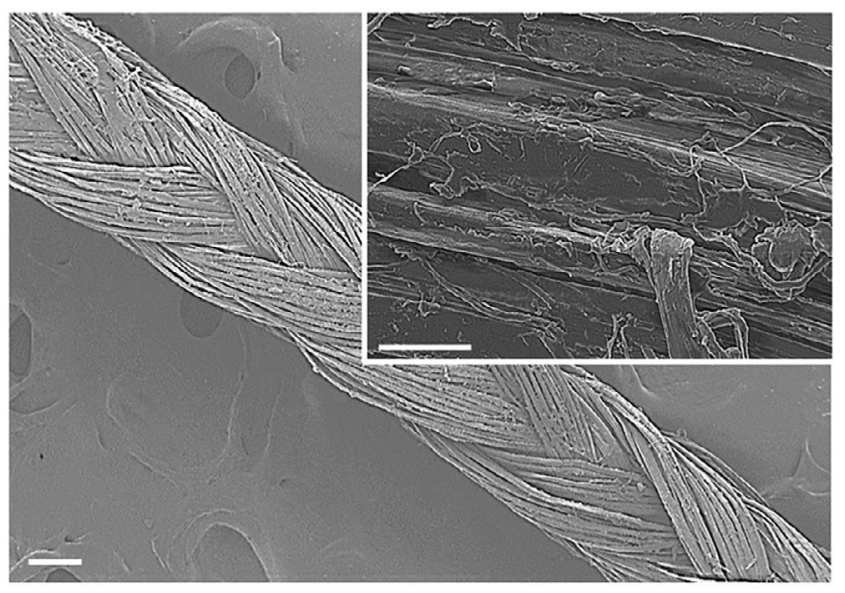

Commercial Perma-Hand $®$ suture

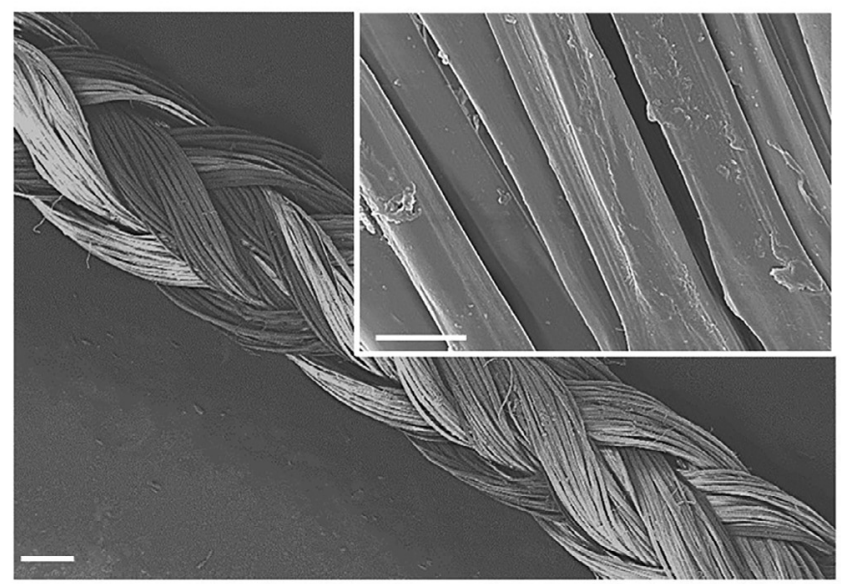

Fig. 2. SEM micrographs of Perma-Hand ${ }^{\circledR}$ suture coated with 6 mer and 6 merHNP1, and uncoated suture. The scale bar corresponds to $10 \mu \mathrm{m}$. Insets are magnified images of SEM images (scale bar corresponds to $1 \mu \mathrm{m}$ ).

The diameter and weight of the sutures coated with 6 mer or 6 mer-HNP1 were significantly higher $(P<0.010)$ when compared to the uncoated sutures (Table 1 ). These are due to the application of different layers of the protein coatings. Since the number of coating cycles may influence suture diameter or weight [16], the mechanical properties of the developed coated sutures were 
Table 1

Diameter and weight of Perma-Hand ${ }^{\circledR}$ sutures coated with 6 mer and 6mr-HNP1, and uncoated Perma-Hand ${ }^{\circledR}$ suture.

\begin{tabular}{lll}
\hline Suture & Diameter $(\mathrm{mm})$ & Weight $(\mathrm{mg})$ \\
\hline $\begin{array}{c}\text { Perma-Hand }{ }^{\circledR} \text { suture } \\
\text { coated with 6mer }\end{array}$ & $0.31 \pm 0.04 \mathrm{~b}$ & $0.52 \pm 0.04 \mathrm{~b}$ \\
$\begin{array}{c}\text { Perma-Hand } \\
\text { coated with 6mer-HNP1 }\end{array}$ & $0.30 \pm 0.02 \mathrm{~b}$ & $0.47 \pm 0.05 \mathrm{~b}$ \\
Commercial Perma-Hand $^{\circledR}$ suture & $0.23 \pm 0.03 \mathrm{a}$ & $0.30 \pm 0.01 \mathrm{a}$ \\
\hline
\end{tabular}

Means \pm SD with different letters in the same column differed significantly according to Tukey's Multiple Range test at $\mathrm{P}<0.05$.

assessed under tensile conditions, by straight-pull and knot-pull tensile test.

In the straight-pull test, the maximum tensile strength of the sutures coated with 6 mer or 6 mer-HNP1 (37 $\pm 6 \mathrm{MPa}$ and $39 \pm 7 \mathrm{MPa}$, respectively) showed no significant differences $(\mathrm{P}>0.05)$ when compared to the uncoated sutures $(47 \pm 9 \mathrm{MPa})$ (Table 2). Likewise, the strain at the breaking point of the coated sutures with 6 mer or 6 mer-HNP1 $(22 \pm 2 \%, 22 \pm 1 \%$, respectively) remains similar $(\mathrm{P}<0.05)$ to the uncoated sutures $(24 \pm 1 \%)$ (Table 2). These results demonstrated that the presence of bioengineered protein coating on commercialized silk sutures have no effect on suture maximum tensile strength and breaking point.

The tensile modulus of the sutures coated with 6 mer was significantly lower $(\mathrm{P}<0.050)$ when compared to the uncoated sutures $(12 \pm 2 \mathrm{GPa})$ or coated with 6 mer-HNP1 (12 $\pm 1 \mathrm{GPa}$, respectively) (Table 2). This difference could be due to the insertion of specific domains into the spider silk segment, which can interfere with the ability of silk to form $\beta$-strands, leading in a change in assembly and thus, in mechanical properties [51]. The strength of bioengineered spider silk proteins reside in the interactions between $\beta$ sheet regions as polyAla, responsible for its higher tensile strength $[52,53]$. Although $\beta$-sheet form weak hydrogen bonds, posttreatment with organic solvents (like methanol) can provide extra tensile strength to the spider silk motifs. The higher stiffness on sutures coated with 6mer-HNP1 compared to sutures coated with 6 mer could be due to the hydrogen bonds between spider silk chain segments and HNP1 domain. In our previous study [39], higher $\beta$-strands of the protein 6mer-HNP1 were observed compared to the protein 6 mer, because of an increase in the number hydrogen bonds in the 6mer-HNP1 proteins. These differences are due to the insertion of HNP1 domain in the 6mer, resulting in an increase of hydrogen bonds between spider silk and HNP1 and thus, the sutures coated with 6mer-HNP1 were stiffer $[51,54]$. Despite the fact that the sutures coated with 6mer-HNP1 showed a significantly higher diameter than the uncoated sutures, their tensile properties were not affect by the coating.

In the knot-pull test, the maximum tensile strength of the sutures uncoated and coated with 6mer or 6mer-HNP1 showed no significant differences $(P>0.05)$ (Table 2$)$. Concerning the tensile modulus and strain at break point on the knot-pull tests, no significant differences $(P>0.05)$ between the coated and uncoated sutures were also observed (Table 2). For instance, the tensile modulus of the sutures coated with 6 mer was $4 \pm 1 \mathrm{GPa}, 4 \pm 1 \mathrm{GPa}$ for 6 mer-HNP1 and for uncoated ones were $5 \pm 1 \mathrm{GPa}$; whereas, the strain at break point was $14 \pm 1 \%, 16 \pm 1 \%$, and $18 \pm 2 \%$, respectively. From the knot-pull tests, it is important to emphasize that the strength values of the coated sutures with 6 mer or $6 \mathrm{mer}$ HNP1 (40.5 or $43.1 \mathrm{GPa}$, respectively) were higher compared with the values ( $31.3 \mathrm{GPa}$ or $14.1 \mathrm{~N}$ ) required by the USP 29-NF 24 for non-absorbable sutures with a USP size of 2-0 (or Gauge size of 3 ). Overall it can be said that 6mer-HNP1 coating does not affect the mechanical properties (straight-pull and knot-pull tests) of silk sutures, whereas sutures coated with 6 mer show a lesser performance when compared to the commercial sutures. Therefore, the new protein coating (6mer-HNP1) do not compromise the function of the material, maintaining the desirable tensile and knot strength.

\subsection{In vitro degradation}

The degradation behavior of silk biomaterials is a very important feature for medical applications in vivo [55], since the structure and morphology of silk sutures or coatings depend on the crystallinity of the $\beta$-sheets structures [56]. In the present study, the in vitro degradation of the sutures coated with 6 mer or 6mer-HNP1 and uncoated sutures were evaluated in PBS with and without protease XIV (Fig. 3).

In the presence of protease XIV, no significant differences $(P>0.05)$ were observed between the coated and uncoated sutures after 1 day of incubation (Fig. 3A). The weight loss of the sutures coated with 6 mer was $25 \pm 3 \% \%$, sutures coated with 6 mer-HNP1 was $29 \pm 1 \%$, and uncoated sutures was $20 \pm 8 \%$ (Fig. 3A). After 4 days of incubation in the presence of protease XIV, sutures coated with 6mer-HNP1 showed a significant $(\mathrm{P}<0.050)$ higher weight loss profile $(42 \pm 8 \%)$ when compared to the sutures coated with 6 mer or uncoated sutures $(23 \pm 7 \%$ and $23 \pm 9 \%$, respectively; Fig. 3A). However, after 7 days in the presence of protease XIV no substantial differences $(P>0.05)$ were observed in the degradation profile of sutures uncoated and coated with 6mer or 6mer-HNP1 (Fig. 3A). The weight loss of suture coated with 6 mer and 6 merHNP1 was $25 \pm 20 \%$ and $41 \pm 11 \%$, respectively, whereas the uncoated Perma-Hand $^{\circledR}$ sutures had a weight loss of $38 \pm 14 \%$ (Fig. 3A). Overall, the in vitro degradation behavior of suture coated with 6 mer-HNP1 seems to follow the same pattern as the uncoated sutures, in the presence of protease XIV, suggesting that their degradation profile could be related to the erosion of the suture surface and not from the bulk degradation of the suture material itself. Commercial Perma-Hand ${ }^{\circledR}$ sutures are coated with wax or silicone to prevent fraying [56] and fast in vitro degradation. Suture coated with 6 mer show a fast degradation of the 6mer coating after 1 day in the presence of protease XIV. However, after day 4 , the degradation profile seems to have reach a limit, possibly due to limited availability of coating to the enzyme's active site. Spider silk coatings have a high content in $\beta$-sheet that confers protection

Table 2

Mechanical properties of Perma-Hand ${ }^{\circledR}$ sutures coated with 6 mer and $6 \mathrm{mr}-\mathrm{HNP1}$, and uncoated Perma-Hand ${ }^{\circledR}$ suture.

\begin{tabular}{|c|c|c|c|c|}
\hline Test type & Suture & Maximum tensile strength (GPa) & Breaking strain (\%) & Tensile modulus (GPa) \\
\hline Straight-pull test & $\begin{array}{l}\text { Perma-Hand }{ }^{\circledR} \text { suture coated with } 6 \text { mer } \\
\text { Perma-Hand }{ }^{\circledR} \text { suture coated with } 6 \text { mer-HNP1 } \\
\text { Commercial Perma-Hand }{ }^{\circledR} \text { suture }\end{array}$ & $\begin{array}{l}37 \pm 6 a \\
39 \pm 7 \mathrm{a} \\
47 \pm 9 \mathrm{a}\end{array}$ & $\begin{array}{l}22 \pm 2 \mathrm{a} \\
22 \pm 1 \mathrm{a} \\
24 \pm 1 \mathrm{a}\end{array}$ & $\begin{array}{l}7 \pm 1 \mathrm{a} \\
12 \pm 2 \mathrm{~b} \\
12 \pm 1 \mathrm{~b}\end{array}$ \\
\hline Knot-pull test & $\begin{array}{l}\text { Perma-Hand }{ }^{\circledR} \text { suture coated with } 6 \text { mer } \\
\text { Perma-Hand }{ }^{\circledR} \text { suture coated with } 6 \text { mer-HNP1 } \\
\text { Commercial Perma-Hand }{ }^{\circledR} \text { suture }\end{array}$ & $\begin{array}{l}41 \pm 7 \mathrm{a} \\
43 \pm 4 \mathrm{a} \\
42 \pm 8 \mathrm{a}\end{array}$ & $\begin{array}{l}14 \pm 1 \mathrm{a} \\
16 \pm 1 \mathrm{a} \\
18 \pm 2 \mathrm{a}\end{array}$ & $\begin{array}{l}4 \pm 1 \mathrm{a} \\
4 \pm 1 \mathrm{a} \\
5 \pm 1 \mathrm{a}\end{array}$ \\
\hline
\end{tabular}

Means \pm SD with different letters in the same column differed significantly according to Tukey’s Multiple Range test at $\mathrm{P}<0.05$. 
A

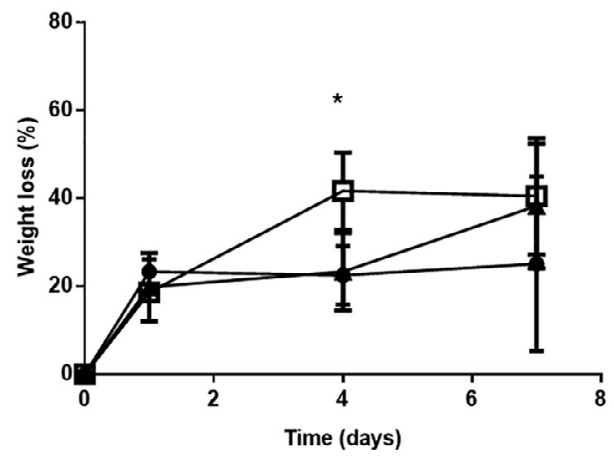

B

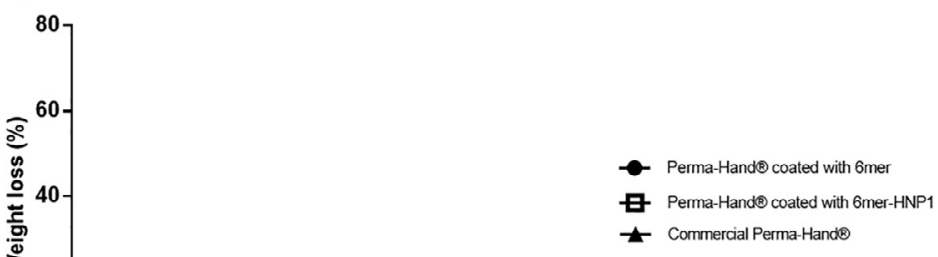

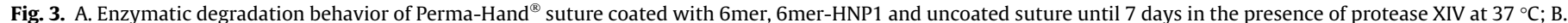
Degradation behavior of Perma-Hand ${ }^{\circledR}$ suture coated with 6 mer, 6 mer-HNP1 and uncoated suture until 7 days in PBS solution (pH 7.4 ) at $37{ }^{\circ} \mathrm{C}$.

against in vitro degradation [57], but they can are still be susceptible to enzymatic degradation leading to differences in material weight and affecting their strength [58]. In addition, the presence of antibacterial spider silk coatings on silk surgical sutures had no significant effect on the biodegradability of the suture itself, maintaining enough structural integrity on the suture throughout the degradation study.

As for sutures in PBS and devoid of enzymes, the weight loss of the sutures coated with 6 mer $(8 \pm 2 \%), 6$ mer-HNP1 $(8 \pm 1 \%)$, and uncoated sutures $(9 \pm 5 \%)$ did not change significantly after 7 days of incubation (Fig. 3B). Results suggest that both coated and uncoated sutures showed a similar degradation pattern in PBS.

\subsection{Antibacterial properties}

Human-derived antimicrobial peptides, like HNP1, have gained great attention as a novel class of antimicrobial compounds due to their broad-spectrum activity against Gram-positive, Gramnegative, fungi or virus, as well as their effectiveness against multi-resistant pathogenic microorganisms like MRSA [59]. Unlike antibiotics, the development of microbial resistant strains to these peptides remains a rare phenomenon since they target specific features on the microbial cellular membrane [25]. Moreover, these antimicrobial peptides play an important role in human innate and adaptive immune response, conferring a high degree of plasticity but slower response to any attack $[25,60]$. The braided nature of the silk sutures can work as a suitable surface for the adherence of bacteria and inducing the formation of biofilms, in which creates a niche for infections that can result in SSI [23,59].

Herein, the viability and adherence of MRSA and E. coli on the surface of the Perma-Hand ${ }^{\circledR}$ sutures coated with 6 mer and 6 merHNP1 were assessed after $24 \mathrm{~h}$ growth (Fig. 4). VicrylPlus ${ }^{\circledR}$, an antibacterial suture, and uncoated Perma-Hand ${ }^{\circledR}$ were used as reference material since there are no commercially available antibacterial silk sutures. Bacterial log reductions were calculated referred to uncoated Perma-Hand ${ }^{\circledR}$ suture.

Perma-Hand ${ }^{\circledR}$ sutures coated with 6mer-HNP1 showed a significant $(\mathrm{P}<0.50)$ inhibitory effect against MRSA and $E$. coli bacteria when compared to sutures coated with 6 mer or uncoated sutures (Fig. 4). As can be observed, Perma-Hand ${ }^{\circledR}$ sutures coated with 6 mer-HNP1 demonstrated a significant $(P<0.001) 1.5$ log reduction of MRSA and a $2 \log$ reduction against $E$. coli when compared to the uncoated Perma-Hand ${ }^{\circledR}$ suture. In contract, Perma-Hand ${ }^{\circledR}$ sutures coated with 6 mer show a $0.5 \log$ reduction of MRSA and a $1 \log$ reduction of $E$. coli. VicrylPlus ${ }^{\circledR}$ shows a log reduction of 2 against the tested bacteria. (Fig. 4). Previous study [23] reported
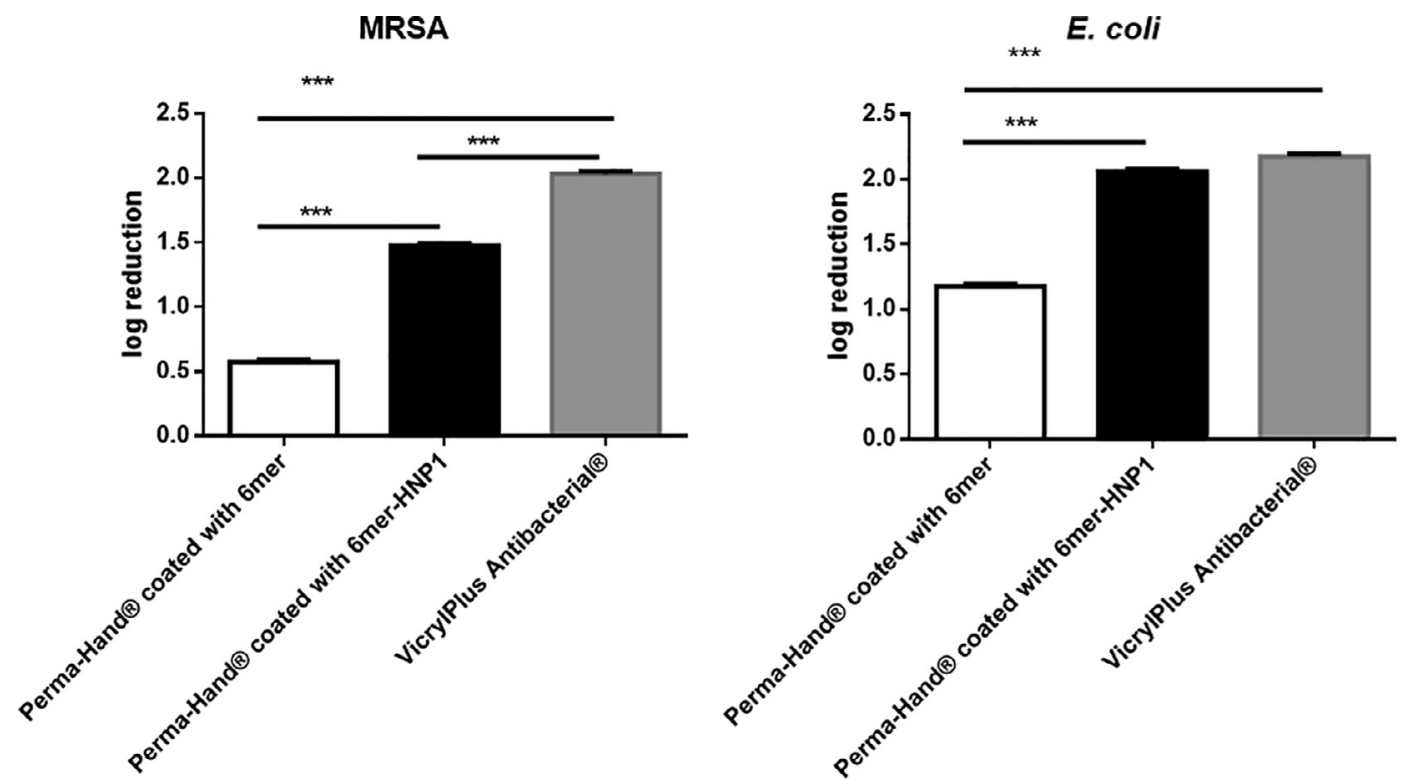

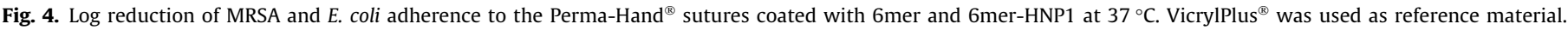
Bacterial log reductions were calculated referred to uncoated Perma-Hand ${ }^{\circledR}$ suture. 
that the incorporation of antimicrobial agents such as silver ions, as silk suture coatings showed an inhibitory effect against $S$. aureus. Similarly, Dhas et al. [61] demonstrated that silk sutures coated with a biobased silver nanocolloid polymer showed an inhibitory effect against Pseudomonas aeruginosa and S. aureus growth. In our study, a significant reduction in the adherence of MRSA and $E$. coli onto the surface of the silk sutures coated with 6merHNP1 was observed after $24 \mathrm{~h}$ of incubation (Fig. 4), suggesting that 6 mer-HNP1 coating also shows an anti-adhesive potential.

The adherence and formation of biofilm of MRSA and E. coli on all type of sutures was observed by SEM and fluorescence microscopy (Fig. 5). MRSA and E. coli were able to adhere onto the surface of Perma-Hand ${ }^{\circledR}$ sutures coated with 6 mer, leading to the formation of bacterial biofilm after $24 \mathrm{~h}$ incubation (Fig. 5A). The same trend was observed with the uncoated Perma-Hand ${ }^{\circledR}$ sutures (Fig. 5A). Regarding the Perma-Hand ${ }^{\circledR}$ sutures coated with 6merHNP1, the adherence and proliferation of MRSA and E. coli decreased, while the formation of biofilm was not observed $24 \mathrm{~h}$ incubation (Fig. 5A). The bacterial adhesion and formation of biofilm on the surface of VicrylPlus ${ }^{\circledR}$ antibacterial sutures exhibited the same inhibitory activity that of the Perma-Hand ${ }^{\circledR}$ sutures coated with 6mer-HNP1 (Fig. 5A). Gómez-Alonso et al. [62] reported that VicrylPlus ${ }^{\circledR}$ antibacterial sutures demonstrate an inhibitory behavior against $S$. aureus and E. coli, which are in line with the results obtained in the present work. The outcome from this antibacterial assessment suggests that Perma-Hand ${ }^{\circledR}$ sutures coated with 6mer-HNP1 exhibit the similar antibacterial behavior when compared to VicrylPlus ${ }^{\circledR}$ antibacterial sutures. Moreover, the presence of 6mer-HNP1 coating on Perma-Hand ${ }^{\circledR}$ sutures induced a reduction on bacteria adhesion on suture surface. Thus, the application of the bioengineered spider silk protein, 6mer-HNP1, as an antibacterial coating could envisage a new class of drug-free sutures, as a promising alternative to replacing the use of sutures with antibiotics.

\subsection{In vitro response}

Regarding the cell metabolic activity, no significant differences $(\mathrm{P}>0.05)$ was observed between all sutures (Fig. 6A). After 1 day of culture, no significant differences $(\mathrm{P}>0.05)$ in cell proliferation
A
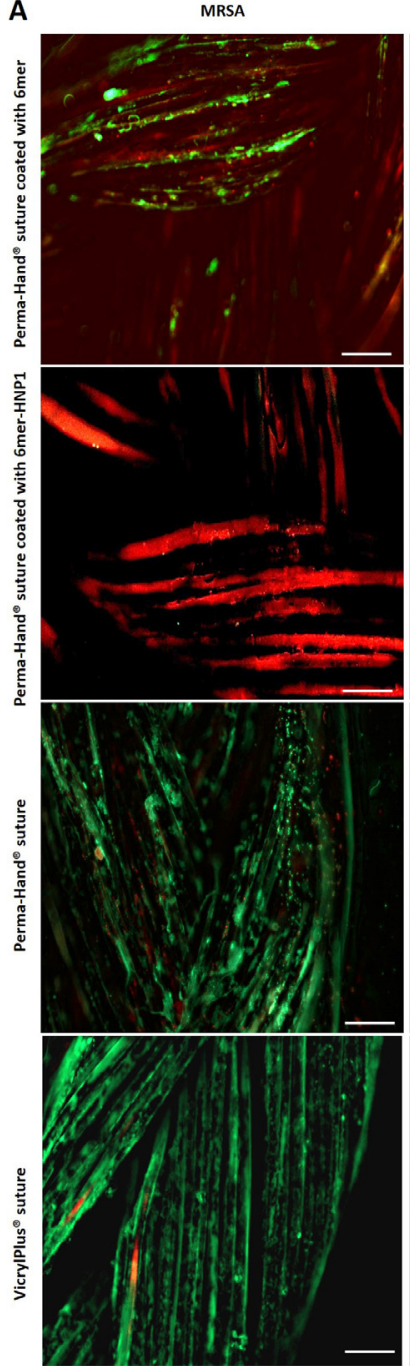

E. coli
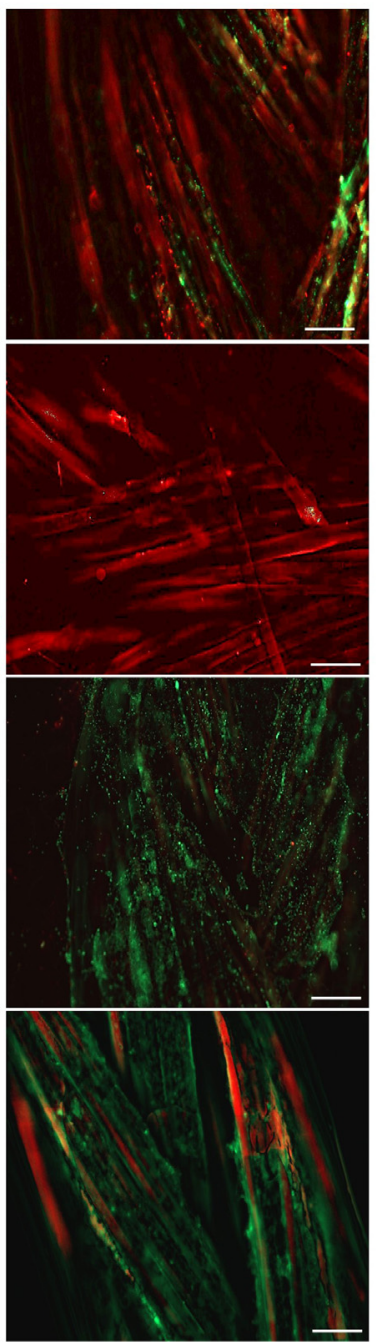

B
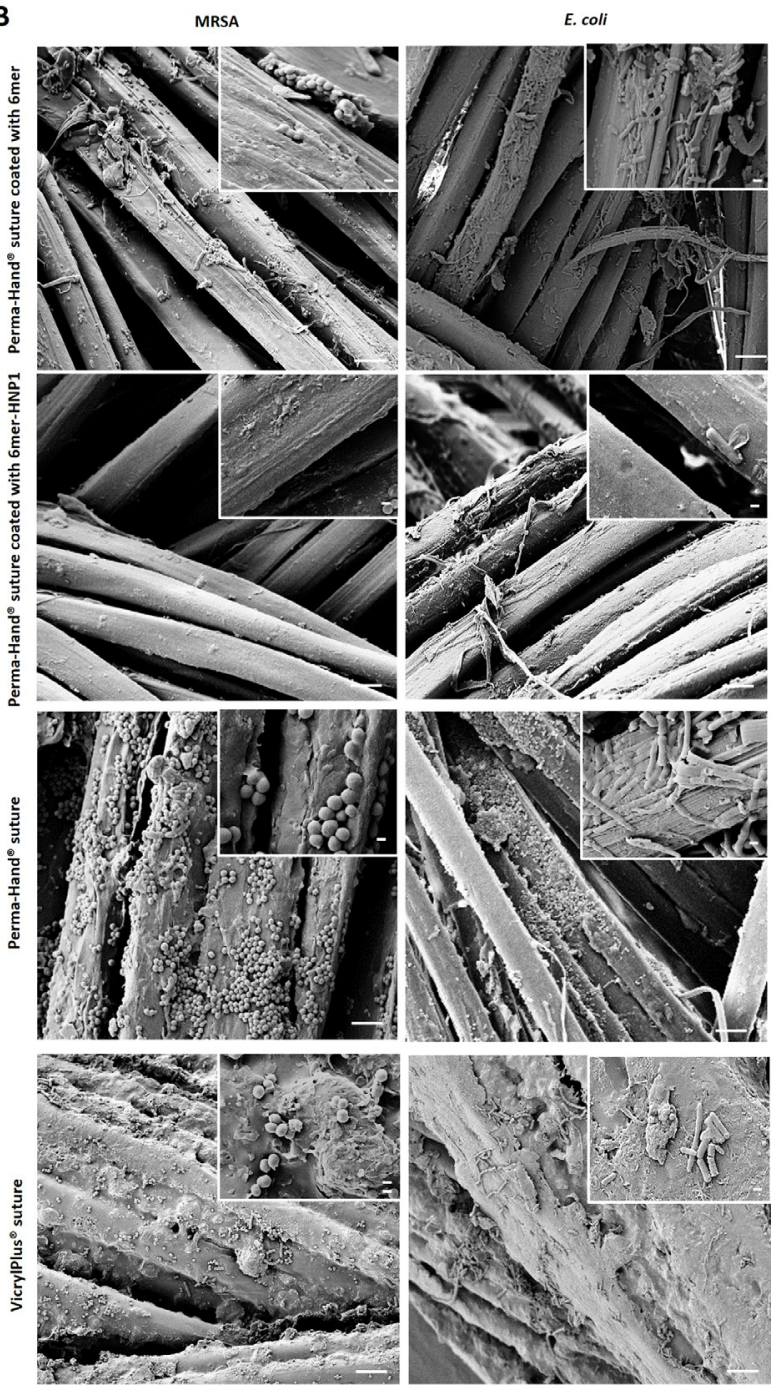

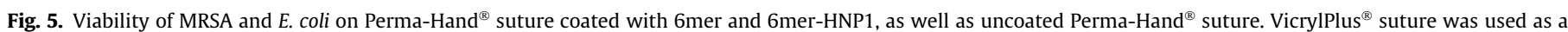

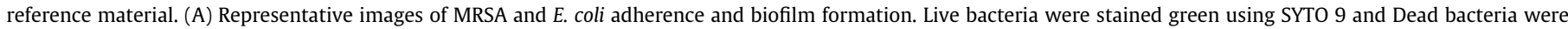

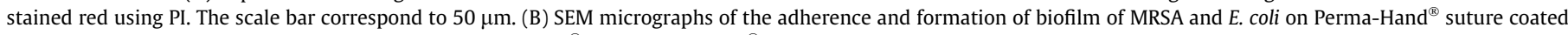

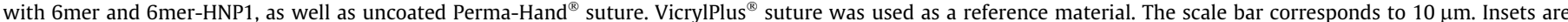

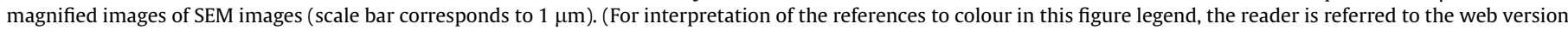
of this article.) 
A

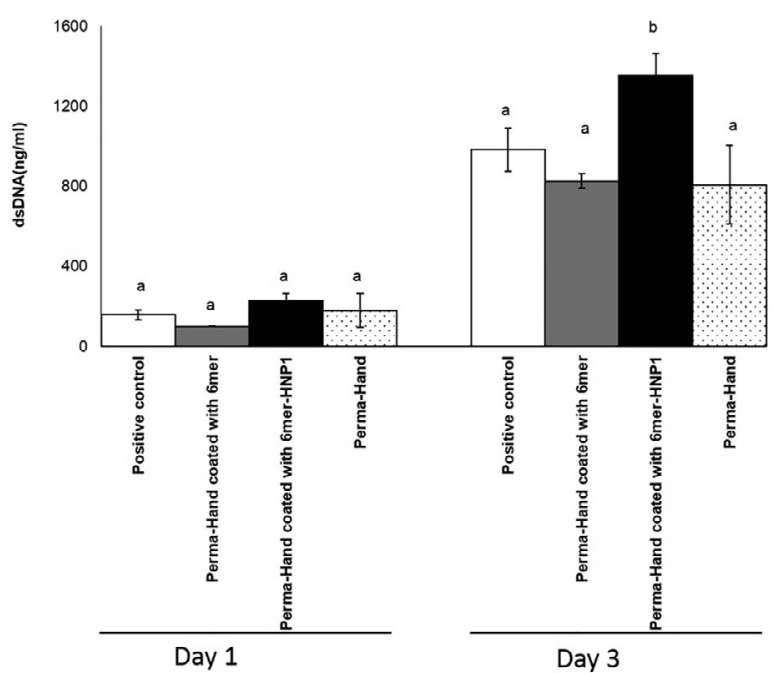

B

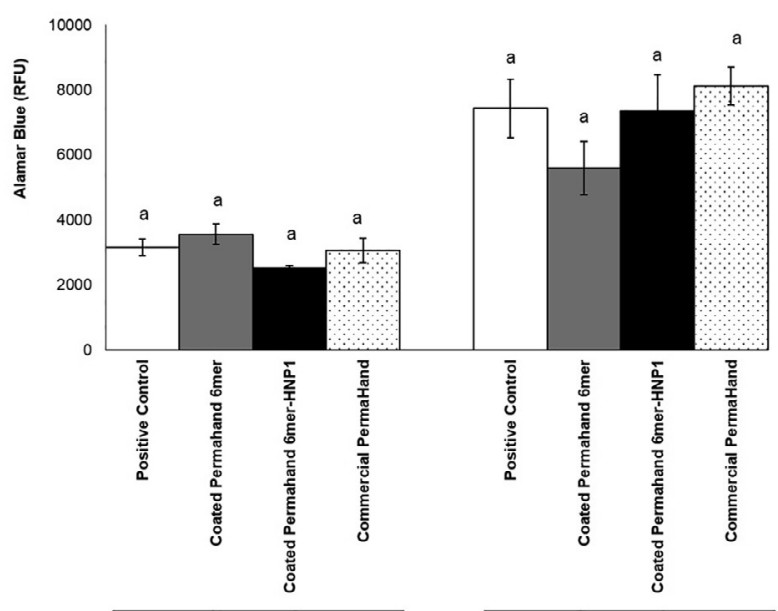

Day 1

Day 3

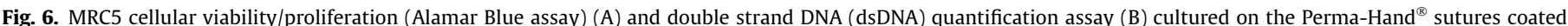

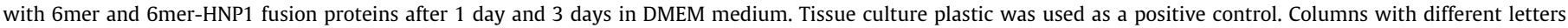
differed significantly according to Tukey Multiple Range test at $\mathrm{P}<0.05$.

were observed between the sutures coated with $6 \mathrm{mer}$ or $6 \mathrm{mer}$ HNP1 and the uncoated sutures (Fig. 6B). Nevertheless, after 3 days of culture, the sutures coated with 6mer-HNP1 showed a significantly higher cell proliferation $(\mathrm{P}<0.05)$ than the other sutures.

Furthermore, when cell viability/proliferation results for all sutures were compared with the positive control, no significant differences were observed $(\mathrm{P}<0.05)$ (Fig. 6).

Biocompatibility studies showed that Perma-Hand ${ }^{\circledR}$ sutures either coated with 6 mer or 6 mer-HNP1 support cell viability and proliferation (Fig. 6). These results further support the positive cellular response of the 6mer and 6mer-HNP1 fusion proteins when used as suture coatings together with antibacterial properties.

\subsection{Hemolytic activity}

The hemolytic activity of the sutures (either coated with 6 mer or 6mer-HNP1, or uncoated) showed a lower significant hemolytic activity $(\mathrm{P}<0.05)$ in contrast to the reference materials (silicone, rubber, and steel) (Fig. 7). Comparing with uncoated PermaHand $^{\circledR}$ sutures as reference material, no significant differences $(P>0.05)$ were observed.

The hemolytic behavior is a common complication affecting the compatibility of medical devices when in contact with blood, which can lead to organ failure [63]. The interaction of implementable materials, like sutures with blood, can result in the release of hemoglobin [44], influenced by the surface of the material [64]. Spider silk proteins are known for their low immunogenicity response in vivo and good biocompatibility, making them suitable for numerous medical applications [65,66]. Likewise, HNP1 as well as analog proteins without cysteine, had reduced activity lysing human red blood cells, possibly due to the high hydrophobicity of HNP1, thus suggesting that HNP1 has no hemolytic activity when in solution [67]. Moreover, HNP1 prevented hemolysis by three cytolysins studied [68], thus suggesting that HNP1 also has no hemolytic activity. In the present study, the bioengineered spider silk protein 6mer-HNP1 showed no hemolytic activity when applied as coatings for silk sutures, as well as the bioengineered protein $6 \mathrm{mer}$, suggesting that they present good blood compatibility.

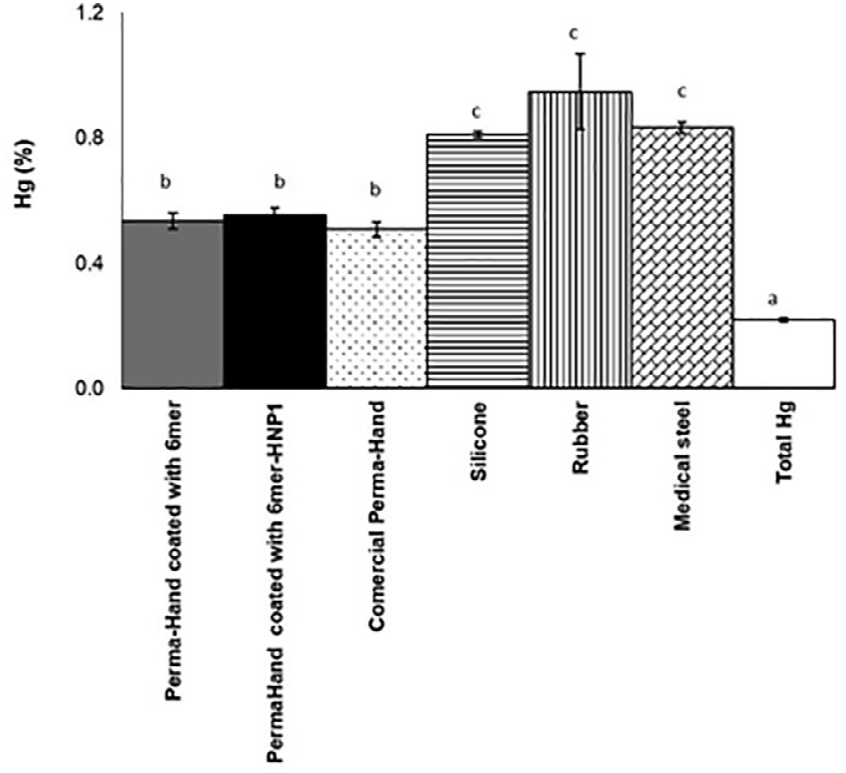

Fig. 7. Haemolysis (\%) of Perma-Hand ${ }^{\circledR}$ sutures coated with 6 mer and 6 mer-HNP1 fusion proteins, and commercial Perma-Hand ${ }^{\circledR}$ sutures. The reference materials, silicone, rubber, and medical steel, were used positive hemolysis reference controls. Total Hg (Total hemoglobin) represent the total lysed hemoglobin without any material and was used as negative control.

\section{Conclusions}

In this study, we have demonstrated the positive effect of using spider silk proteins functionalized with antimicrobial peptide (6mer-HNP1) as a coating for silk sutures preventing/eliminating or substantially reducing the extent of bacterial attachment and biofilm formation on their surfaces. The coated sutures retained tensile and knot strength, maintaining silk suture inherent performance, surface morphology and in vitro biodegradability. In addition, significant inhibition of MRSA and E. coli adhesion was observed as well as good cytotoxicity and hemolytic properties. 
The importance of this in vitro study relies on the engineering new spider silk polymer proteins with antimicrobial peptides to prevent SSI, and at the same time avoiding the utilization of antimicrobial agents or antibiotics. This new antibacterial suture coating for silk sutures represents a potentially important option for antibioticfree sutures. Nevertheless, further studies are necessary to explore the inflammatory response as well as mechanical behavior of these new antibacterial coatings in vivo, to fully address the potential of this approach for sutures or other medical devices.

\section{Acknowledgments}

This work was supported by the Portuguese Foundation for Science and Technology (FCT) under the projects PTDC/BBB$\mathrm{BIO} / 0827 / 2012$ and POCI-01-0145-FEDER-007038 (UID/ Multi/50026/2013), and by the European Regional Development Fund (FEDER) through the "COMPETE" - Operational Program for Competitiveness factors (FCOMP-01-0124-FEDER-028120). A.R. Franco thanks FCT through the Post-Doctoral scholarship SFRH/ BPD/100760/2014. FR was funded under the scope of the project NORTE-01-0145-FEDER-000023, supported by the Northern Portugal Regional Operational Program (NORTE 2020), under the Portugal 2020 Partnership Agreement through FEDER. ARF, IBL, and DLK designed the study. ARF and DLK carried out all the experiments. ARF and EMF analyzed the mechanical data. ARF, MTR, and MEG analyzed the biocompatibility and hemolysis assay data. ARF and FJR performed the antibacterial studies. IBL, DLK, and RLR were involved supervised the work. All authors provided critical feedback and helped shape the research, analysis and manuscript.

\section{References}

[1] X. Ding, S. Duan, X. Ding, R. Liu, F.-J. Xu, Versatile antibacterial materials: an emerging arsenal for combatting bacterial pathogens, Adv. Funct. Mater. 28 (2018) 1802140.

[2] C. Suetens, S. Hopkins, J. Kolman, L. Diaz Högberg (Eds.), Healthcare associated, European Centre for Disease Prevention and Control. Point prevalence survey of Hospitals, infections and antimicrobial use in European acute care, ECDC Stockholm, 2013

[3] M. Zong, L. Bai, Y. Liu, X. Wang, X. Zhang, X. Huang, R. Hang, B. Tang, Antibacterial ability and angiogenic activity of $\mathrm{Cu}-\mathrm{Ti}-\mathrm{O}$ nanotube arrays, Mater. Sci. Eng. C 71 (2017) 93-99.

[4] R.M. Klevens, J.R. Edwards, C.L. Richards Jr., T.C. Horan, R.P. Gaynes, D.A. Pollock, D.M. Cardo, Estimating health care-associated infections and deaths in U.S. hospitals, 2002, Public Health Rep. 122 (2007) 160-166.

[5] P.W. Stone, Economic burden of healthcare-associated infections: an American perspective, Expert Rev. Pharmacoecon. Outcomes Res. 9 (2010) 417-422.

[6] S. Goodman, Z. Yao, M. Keeney, Yang Fan, The future of biologic coatings for orthopaedic implants Stuart, Biomaterials 509 (2014) 385-388.

[7] E. Skeie, A.M. Koch, S. Harthug, U. Fosse, K. Sygnestveit, R.M. Nilsen, R.J. Tangvik, A positive association between nutritional risk and the incidence of surgical site infections: a hospital-based register study, PLoS One 13 (2018) 1 10.

[8] A. Obermeier, J. Schneider, S. Wehner, F.D. Matl, M. Schieker, R. von EisenhartRothe, A. Stemberger, R. Burgkart, Novel high efficient coatings for antimicrobial surgical sutures using chlorhexidine in fatty acid slow-release carrier systems, PLoS One 9 (2014) e101426.

[9] A. Obermeier, J. Schneider, N. Harrasser, J. Tübel, H. Mühlhofer, D. Pförringer, C. von Deimling, P. Foehr, B. Kiefel, C. Krämer, A. Stemberger, M. Schieker, R. Burgkart, R. Von Eisenhart-Rothe, Viable adhered Staphylococcus aureus highly reduced on novel antimicrobial sutures using chlorhexidine and octenidine to avoid surgical site infection (SSI), PLoS One 13 (2018) 1-20.

[10] H.H. Tuson, D.B. Weibel, Bacteria-surface interactions, Soft Matter 9 (2013) 4368.

[11] J. Sjollema, S.A.J. Zaat, V. Fontaine, M. Ramstedt, R. Luginbuehl, K. Thevissen, J. Li, H.C. van der Mei, H.J. Busscher, In vitro methods for the evaluation of antimicrobial surface designs, Acta Biomater. 70 (2018) 12-24.

[12] B.D. Masini, D.J. Stinner, S.M. Waterman, J.C. Wenke, Bacterial adherence to suture materials, J. Surg. Educ. 68 (2011) 101-104.

[13] G. Li, Y. Li, G. Chen, J. He, Y. Han, X. Wang, D.L. Kaplan, Silk-based biomaterials in biomedical textiles and fiber-based implants, Adv. Healthc. Mater. 4 (2015) $1134-1151$.

[14] G.H. Altman, F. Diaz, C. Jakuba, T. Calabro, R.L. Horan, J. Chen, H. Lu, J. Richmond, D.L. Kaplan, Silk-based biomaterials, Biomaterials 24 (2003) 401416.
[15] R. Costa-Almeida, I. Calejo, R. Altieri, R.M.A. Domingues, E. Giordano, R.L. Reis, M.E. Gomes, Exploring platelet lysate hydrogel-coated suture threads as biofunctional composite living fibers for cell delivery in tissue repair, Biomed. Mater. 14 (2019) 34104.

[16] M. Champeau, J.-M. Thomassin, T. Tassaing, C. Jérôme, Current manufacturing processes of drug-eluting sutures, Expert Opin. Drug Deliv. 14 (2017) 1-11.

[17] X. Chen, D. Hou, L. Wang, Q. Zhang, J. Zou, G. Sun, Antibacterial surgical silk sutures using a high-performance slow-release carrier coating system, ACS Appl. Mater. Interfaces 7 (2015) 22394-22403.

[18] S. Viju, G. Thilagavathi, Characterization of tetracycline hydrochloride drug incorporated silk sutures, J. Text. Inst. 104 (2013) 289-294.

[19] D.J. Hess, M.J. Henry-Stanley, C.L. Wells, Gentamicin promotes Staphylococcus aureus biofilms on silk suture, J. Surg. Res. 170 (2011) 302-308.

[20] P. Janiga, B. Elayarajah, R. Rajendran, R. Rammohan, B. Venkatrajah, S. Asa, Drug-eluting silk sutures to retard post-operative surgical site infections, J. Ind. Text. 42 (2012) 176-190.

[21] M.M. Umair, Z. Jiang, N. Ullah, W. Safdar, Z. Xie, X. Ren, Development and characterisation of antibacterial suture functionalised with N-halamines, J Ind. Text. 46 (2016) 59-74.

[22] S. Pethile, X.-J. Chen, D. Hou, L. Wang, Effect of changing coating process parameters in the preparation of antimicrobial-coated silk sutures: an in vitro study, Fibers Polym. 15 (2014) 1589-1595.

[23] S. De Simone, A.L. Gallo, F. Paladini, A. Sannino, M. Pollini, Development of silver nano-coatings on silk sutures as a novel approach against surgical infections, J. Mater. Sci. Mater. Med. 25 (2014) 2205-2214.

[24] C.R. Arciola, D. Campoccia, L. Montanaro, Implant infections: adhesion, biofilm formation and immune evasion, Nat. Rev. Microbiol. 16 (2018) 397-409.

[25] M. Zasloff, Antimicrobial peptides of multicellular organisms, Nature 415 2002) 389-395

[26] B. Casciaro, F. Cappiello, M. Cacciafesta, M.L. Mangoni, Promising approaches to optimize the biological properties of the antimicrobial peptide esculentin1a(1-21)NH2: amino acids substitution and conjugation to nanoparticles, Front. Chem. 5 (2017) 1-7.

[27] L.T. Nguyen, H.J. Vogel, Structural perspectives on antimicrobial chemokines, Front. Immunol. 3 (2012) 1-11.

[28] M.E. Pachón-Ibáñez, Y. Smani, J. Pachón, J. Sánchez-Céspedes, Perspectives for clinical use of engineered human host defense antimicrobial peptides, FEMS Microbiol. Rev. 41 (2017) 323-342.

[29] K.M. Varney, A.M.J.J. Bonvin, M. Pazgier, J. Malin, W. Yu, E. Ateh, T. Oashi, W. Lu, J. Huang, M. Diepeveen-de Buin, J. Bryant, E. Breukink, A.D. MacKerell, E.P.H. de Leeuw, Turning defense into offense: defensin mimetics as novel antibiotics targeting lipid II, PLoS Pathog. 9 (2013) e1003732.

[30] B. Ericksen, Z. Wu, W. Lu, R.I. Lehrer, Antibacterial activity and specificity of the antibacterial activity and specificity of the six, Antimicrob. Agents Chemother. 49 (2005) 8-15.

[31] E. de Leeuw, C. Li, P. Zeng, C. Li, M.D. de Buin, W.Y. Lu, E. Breukink, W. Lu, Functional interaction of human neutrophil peptide-1 with the cell wall precursor lipid II, FEBS Lett. 584 (2010) 1543-1548.

[32] S. Dabirian, Y. Taslimi, F. Zahedifard, E. Gholami, F. Doustdari, M. Motamedirad S. Khatami, K. Azadmanesh, S. Nylen, S. Rafati, Human neutrophil peptide-1 (HNP-1): a new anti-leishmanial drug candidate, PLoS Negl. Trop. Dis. 7 (2013).

[33] S. Sharma, I. Verma, G.K. Khuller, Therapeutic potential of human neutrophil peptide 1 against experimental tuberculosis, Antimicrob. Agents Chemother 45 (2001) 639-640.

[34] B. Casciaro, M. Moros, S. Rivera-Fernández, A. Bellelli, J.M. de la Fuente, M.L. Mangoni, Gold-nanoparticles coated with the antimicrobial peptide esculentin-1a(1-21)NH2 as a reliable strategy for antipseudomonal drugs, Acta Biomater. 47 (2017) 170-181.

[35] A. Rising, M. Widhe, J. Johansson, M. Hedhammar, Spider silk proteins: Recent advances in recombinant production, structure-function relationships and biomedical applications, Cell. Mol. Life Sci. 68 (2011) 169-184.

[36] R. Jansson, N. Thatikonda, D. Lindberg, A. Rising, J. Johansson, P.Å. Nygren, M Hedhammar, Recombinant spider silk genetically functionalized with affinity domains, Biomacromolecules 15 (2014) 1696-1706.

[37] J.A. Kluge, O. Rabotyagova, G.G. Leisk, D.L. Kaplan, Spider silks and their applications, Trends Biotechnol. 26 (2008) 244-251.

[38] S.C. Gomes, I.B. Leonor, J.F. Mano, R.L. Reis, D.L. Kaplan, Antimicrobia functionalized genetically engineered spider silk, Biomaterials 32 (2011) 4255-4266.

[39] A.R. Franco, E. Palma Kimmerling, C. Silva, F.J. Rodrigues, I.B. Leonor, R.L. Reis, D.L. Kaplan, Silk-based antimicrobial polymers as a new platform to design drug-free materials to impede microbial infections, Macromol. Biosci. 18 (2018) 1800262.

[40] M. Bruschi, G. Pirri, A. Giuliani, S.F. Nicoletto, I. Baster, M.A. Scorciapino, M. Casu, A.C. Rinaldi, Synthesis, characterization, antimicrobial activity and LPSinteraction properties of SB041, a novel dendrimeric peptide with antimicrobial properties, Peptides 31 (2010) 1459-1467.

[41] K. Numata, B. Subramanian, H.A. Currie, D.L. Kaplan, Bioengineered silk protein-based gene delivery systems, Biomaterials 30 (2009) 5775-5784.

[42] Mechanical strength, in: Eur. Pharmacopoeia 5th ed. Main Vol. 5.0, 2005: p. 874.

[43] Tensile Strength, in: United States Pharmacop. Natl. Formul. (USP 29-NF 24), United States Pharmacopeial Convention, Rockville, MD, 2006.

[44] K.V. Nemani, K.L. Moodie, J.B. Brennick, A. Su, B. Gimi, In vitro and in vivo evaluation of SU-8 biocompatibility, Mater. Sci. Eng. C 33 (2013) 4453-4459. 
[45] G.N. Tew, D. Clements, H. Tang, L. Arnt, R.W. Scott, Antimicrobial activity of an abiotic host defense peptide mimic, Biochim. Biophys. Acta Biomembr. 1758 (2006) 1387-1392.

[46] M. Harboe, A method for determination of hemoglobin in plasma by nearultraviolet spectrophotometry, Scand. J. Clin. Lab. Invest. 11 (1959) 66-70.

[47] D.M. Tsai, E.J. Caterson, Current preventive measures for health-care associated surgical site infections: a review, Patient Saf. Surg. 8 (2014) 42.

[48] J.R. North, S. Takenaka, A. Rozek, A. Kielczewska, S. Opal, L.A. Morici, B.B. Finlay, C.J. Schaber, R. Straube, O. Donini, A novel approach for emerging and antibiotic resistant infections: innate defense regulators as an agnostic therapy, J. Biotechnol. 226 (2016) 24-34.

[49] O.S, Tokareva, S. Lin, M.M. Jacobsen, W. Huang, D. Rizzo, D. Li, M. Simon, C. Staii, P. Cebe, J.Y. Wong, M.J. Buehler, D.L. Kaplan, Effect of sequence features on assembly of spider silk block copolymers, J. Struct. Biol. 186 (2014) 412 419.

[50] M. Humenik, M. Mohrand, T. Scheibel, Self-assembly of spider silk-fusion proteins comprising enzymatic and fluorescence activity, Bioconjugate Chem. 29 (2018) 898-904.

[51] S. Gomes, K. Numata, LB. Leonor, J.F. Mano, R.L. Reis, D.L. Kaplan, AFM study of morphology and mechanical properties of a chimeric spider silk and bone sialoprotein protein for bone regeneration, Biomacromolecules 12 (2011) 1675-1685.

[52] S. Keten, Z. Xu, B. Ihle, M.J. Buehler, Nanoconfinement controls stiffness, strength and mechanical toughness of beta-sheet crystals in silk, Nat. Mater. 9 (2010) 359-367.

[53] C.Y. Hayashi, N.H. Shipley, R.V. Lewis, Hypotheses that correlate the sequence, structure, and mechanical properties of spider silk proteins, Int. J. Biol Macromol. 24 (1999) 271-275.

[54] J. Pérez-Rigueiro, C. Viney, J. Llorca, M. Elices, Mechanical properties of singlebrin silkworm silk, J. Appl. Polym. Sci. 75 (2000) 1270-1277.

[55] Y. Cao, B. Wang, Biodegradation of silk biomaterials, Int. J. Mol. Sci. 10 (2009) 1514-1524.

[56] C. Vepari, D.L. Kaplan, Silk as a biomaterial, Changes 29 (2012) 997-1003.

[57] A.E. Thurber, F.G. Omenetto, D.L. Kaplan, In vivo bioresponses to silk proteins, Biomaterials 71 (2015) 145-157.
[58] N. Dinjaski, D. Ebrahimi, Z. Qin, J.E.M. Giordano, S. Ling, M.J. Buehler, D.L. Kaplan, Predicting rates of in vivo degradation of recombinant spider silk proteins, J. Tissue Eng. Regen. Med. 12 (2018) e97-e105.

[59] W. Aoki, K. Kuroda, M. Ueda, Next generation of antimicrobial peptides as molecular targeted medicines, J. Biosci. Bioeng. 114 (2012) 365-370.

[60] H.G. Boman, Innate immunity and the normal microflora, Immunol. Rev. 173 (2000) 5-16.

[61] S.P. Dhas, S. Anbarasan, A. Mukherjee, N. Chandrasekaran, Biobased silver nanocolloid coating on silk fibers for prevention of post-surgical wound infections, Int. J. Nanomed. 10 (2015) 159-170.

[62] A. Gómez-Alonso, F.J. García-Criado, F.C. Parreño-Manchado, J.E. GarcíaSánchez, E. García-Sánchez, A. Parreño-Manchado, Y. Zambrano-Cuadrado, Study of the efficacy of coated VICRYL Plus ${ }^{\circledR}$ antibacterial suture (coated polyglactin 910 suture with triclosan) in two animal models of general surgery, J. Infect. 54 (2007) 82-88.

[63] C. Li, B. Cai, J. Jin, J. Liu, X. Xu, J. Yin, L. Yin, Hemocompatible, antioxidative and antibacterial polypropylene prepared by attaching silver nanoparticles capped with TPGS, J. Mater. Chem. B 3 (2015) 8410-8420.

[64] S. Henkelman, G. Rakhorst, J. Blanton, W. van Oeveren, Standardization of incubation conditions for hemolysis testing of biomaterials, Mater. Sci. Eng. C 29 (2009) 1650-1654.

[65] S. Gomes, J. Gallego-Llamas, I.B. Leonor, J.F. Mano, R.L. Reis, D.L. Kaplan, Biological responses to spider silk-antibiotic fusion protein, J. Tissue Eng. Regen. Med. 6 (2012) 356-368.

[66] S. Gomes, J. Gallego-Llamas, I.B. Leonor, J.F. Mano, R.L. Reis, D.L. Kaplan, In vivo biological responses to silk proteins functionalized with bone sialoprotein, Macromol. Biosci. 13 (2013) 444-454.

[67] J. Varkey, R. Nagaraj, Antibacterial activity of human neutrophil defensin HNP1 analogs without cysteines, Antimicrob. Agents Chemother. 49 (2005) 4561 4566.

[68] R.I. Lehrer, G. Jung, P. Ruchala, W. Wang, E.D. Micewicz, A.J. Waring, E.J. Gillespie, K.A. Bradley, A.J. Ratner, R.F. Rest, W. Lu, Human $\alpha$-defensins inhibit hemolysis mediated by cholesterol-dependent cytolysins, Infect. Immun. 77 (2009) 4028-4040. 